Research Article

\title{
Research on Key Technologies of Floor Heave Control in Soft Rock Roadway
}

\author{
Lei Shi, ${ }^{1}$ Haidong Zhang $\mathbb{D}^{2}{ }^{2}$ and Peng Wang ${ }^{1}$ \\ ${ }^{1}$ School of Energy and Mining Engineering, China University of Mining \& Technology (Beijing), Beijing, China \\ ${ }^{2}$ Department of Civil and Architectural Engineering, Shanxi Institute of Technology, Yangquan, China \\ Correspondence should be addressed to Haidong Zhang; zhanghaidong2014@163.com
}

Received 21 April 2020; Revised 8 August 2020; Accepted 21 August 2020; Published 3 September 2020

Academic Editor: Hui Yao

Copyright $(0) 2020$ Lei Shi et al. This is an open access article distributed under the Creative Commons Attribution License, which permits unrestricted use, distribution, and reproduction in any medium, provided the original work is properly cited.

\begin{abstract}
Aiming at the floor heave of transportation concentrated roadway on the West Wing (TCRWW) of No. 1 Coal Seam in Danhou Mine, it affects underground coal transportation and mine safety production. First, the lithology and structure of the roadway floor were sampled and tested, and it was found that it contained clay minerals with high hydrophilicity. Secondly, starting from the mechanical mechanism of the roadway floor, a mechanical model of the roadway floor is established. By increasing the floor anchoring layer thickness $m_{1}$, the floor deformation can be effectively controlled to guarantee the stability of the surrounding rock of the roadway. Thirdly, the FLAC3D numerical simulation analysis of the roadway deformation under the existing support scheme of the roadway is consistent with the measured deformation results on-site, thereby revealing that the existing support scheme and parameters are not reasonable. Finally, the unreasonable support scheme and parameters of the existing roadway were disclosed, and an antifloor arch structure was proposed: "quicklime bottom paving + prestressed anchor cable + concrete arc beam + metal mesh $+\mathrm{C} 20$ high-strength concrete filling." This floor treatment plan is adopted for the industrial verification of the test section of TCRWW. Engineering practice shows that the optimized roadway support scheme has a better effect on the deformation control of the roof-to-floor and rib-to-rib, thereby effectively ensuring safe and efficient production in the mine.
\end{abstract}

\section{Introduction}

With the rapid development of China's economic construction, the demand for coal resources is increasing, and the development of large-scale coal mining equipment has grown up to be a demand. Therefore, the cross section of the underground roadway is required to increase accordingly. Under the influence of the physical and chemical effects of water, the exposed floor after the formation of the roadway quickly softens in a short time. Moreover, under the repeated action of mechanical dynamic load, the muddy failure of rock mass occurs, which seriously affects the requirements of roadway transportation, ventilation, and pedestrians [1]. At the same time, as the mining depth of coal mines increases at a rate of 8-12 m per year, the issue of the soft rock becomes particularly critical [2]. Considering the increase of the cross-sectional area of the soft rock roadway, the floor heave phenomenon becomes more and more prominent under the combined effect of the overburden rock mass, the tectonic stress, and the physical and chemical effects of water. It has gradually become an important feature of roadway pressure and is a technical problem to be resolved urgently [3-6].

For a long time, experts and scholars have done much research on the mechanism and control of floor heave in soft rock roadways. Einstein and Yang $[7,8]$ believed that the hydraulic and mechanical effects are the influencing factors of the floor heave. Jiang et al. [9] believed that the types of roadway floor heave can be subdivided into floor heave of extrusion fluidity, floor heave of flexural folding, floor heave of shear stagger, and floor heave of swelling in case of water. Moreover, the characteristics and mechanism of the floor heave in the coal mine roadway are discussed, so as to provide a theoretical basis for the effective establishment of effective floor heave countermeasures [10]. Among them, the water-induced rock swelling is mainly due to the physical and chemical reaction of water with the clay minerals 
contained in the rock and the fact that the floor heave increases with time. Zhang et al. [11] analyzed the clay mineral composition of the rock mass, as well as the weakening and permeability of the surrounding rock at different stress stages when it encountered water. In particular, the type and content of the chemically active montmorillonite in the mineral composition play a key role in rock expansion $[12,13]$. After the roadway is excavated, the rock mass is easy to be weathered and dehydrated. If it encounters water again, it will all become muddy, disintegrated, and broken. This not only undermines the strength of the rock mass, but also expands the rock mass to produce expansion stresses, which exacerbates the deformation of the floor [14].

In terms of control of the floor heave, Jia et al. [15] believed that the lateral side-cutting pressure relief of the roadway can be used to control the deformation. Xie and Chang [16] proposed the use of grouting anchors and concrete backfill to control the bottom roadway of deep roadways. Zheng et al. [17] used prestressed anchor cables to strengthen the floor of the soft rock roadway to control the floor heave. He et al. [18] proposed the "three-control" theory including roof, rib-to-rib, and floor angles. Huang et al. $[19,20]$ proposed that the basic roof of the cutting roadway under directional hydraulic fracturing drilling can control the deformation.

Scholars have achieved a series of research results in the field of the floor heave prevention and control, such as digging floor method, reinforcement method, pressure relief method, combined support method of the anchor (cable). The deformation of the floor got controlled to some extent using these techniques. However, considering the geological conditions of mines and the diversity of stress occurrence conditions, the existing control measures cannot be fully adapted to different types of floor heave. Thus, the failure of the control of floor heave can still be frequently observed, which seriously restricts the safe and efficient mining of coal mines.

The authors establish a mechanical model to theoretically conduct an in-depth analysis on the floor heave and make a thorough mechanical analysis on the weak rock layer of the floor in the Danhou Mine. Considering the floor heave resulting from the interaction between water and clay minerals, a new control technology, an antifloor arch structure, is proposed to control the floor heave in the mine.

\section{Engineering Survey}

2.1. Background of the Study. The Danhou Coal Mine belongs to Kailuan (Group) Yuzhou Mining Co., Ltd., which is located in Yuxian, Zhangjiakou City, Hebei Province (Figure 1). The mine produces 1.5 million tonnes of coal annually, and the single-level advance method of vertical shaft is adopted. The main coal seams are the No. 6 coal seam, the No. 5 coal seam, and the No. 1 coal seam in order from top to bottom. The comprehensive histogram is given in Figure 2. At present, the No. 5 and No. 6 coal seam of the Danhou Coal Mine have been mined, and the $1103 \mathrm{~N}$ panel in the first mining area of the No. 1 coal seam is being mined. The average cover depth and seam dip angles are $400 \mathrm{~m}$ and $4^{\circ}$,

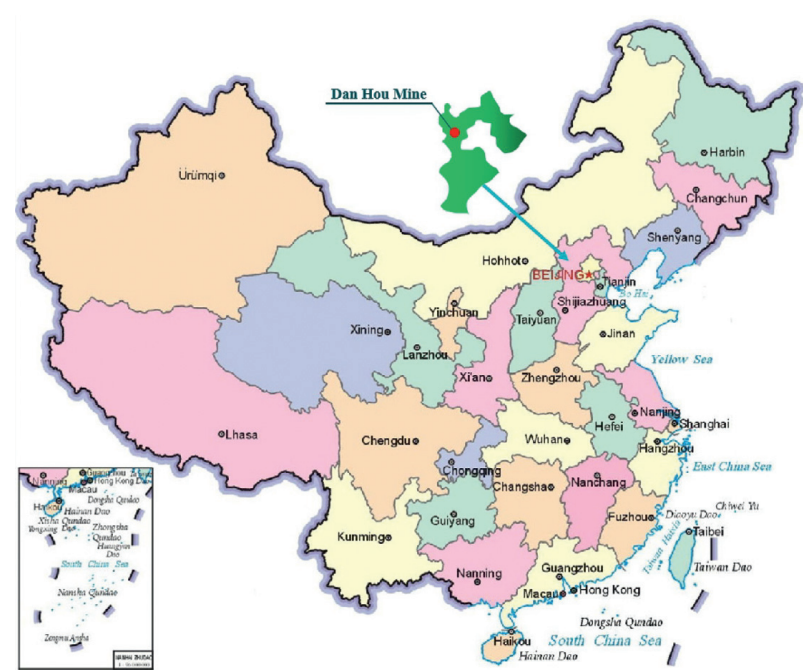

Figure 1: Location of Danhou Mine.

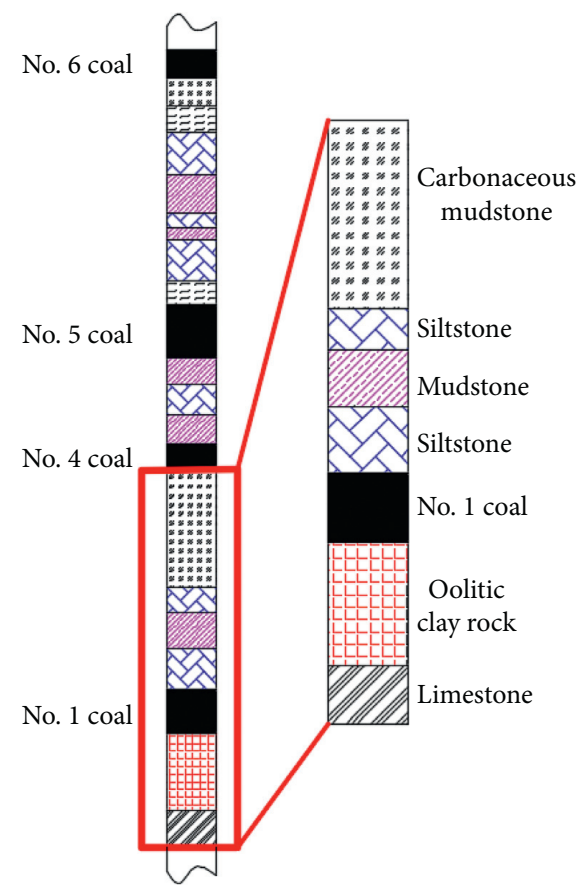

Figure 2: Comprehensive histogram.

respectively. The coal seam is overlain by $0.65 \mathrm{~m}$ of siltstone, $4.65 \mathrm{~m}$ of mudstone, and $2.3 \mathrm{~m}$ of siltstone in ascending order. The coal seam is underlain by oolitic clay rock, partially mudstone, with an average thickness of $9.3 \mathrm{~m}$.

TCRWW mainly provides a coal transportation guarantee for the No. 1 coal seam. The north side is the $1103 \mathrm{~N}$ panel that is being mined, and the south side is the unarranged mining area (Figure 3). Above TCRWW, there is a goaf of the No. 5 coal seam with a distance of $36 \mathrm{~m}$ (no mining activity).

The No. 1 coal seam underlies the Ordovician limestone karst fissure confined aquifer, which is the base of the coal measure, and is the main floor directly filled with water. The distance between the interface of the Austrian ash roof and 


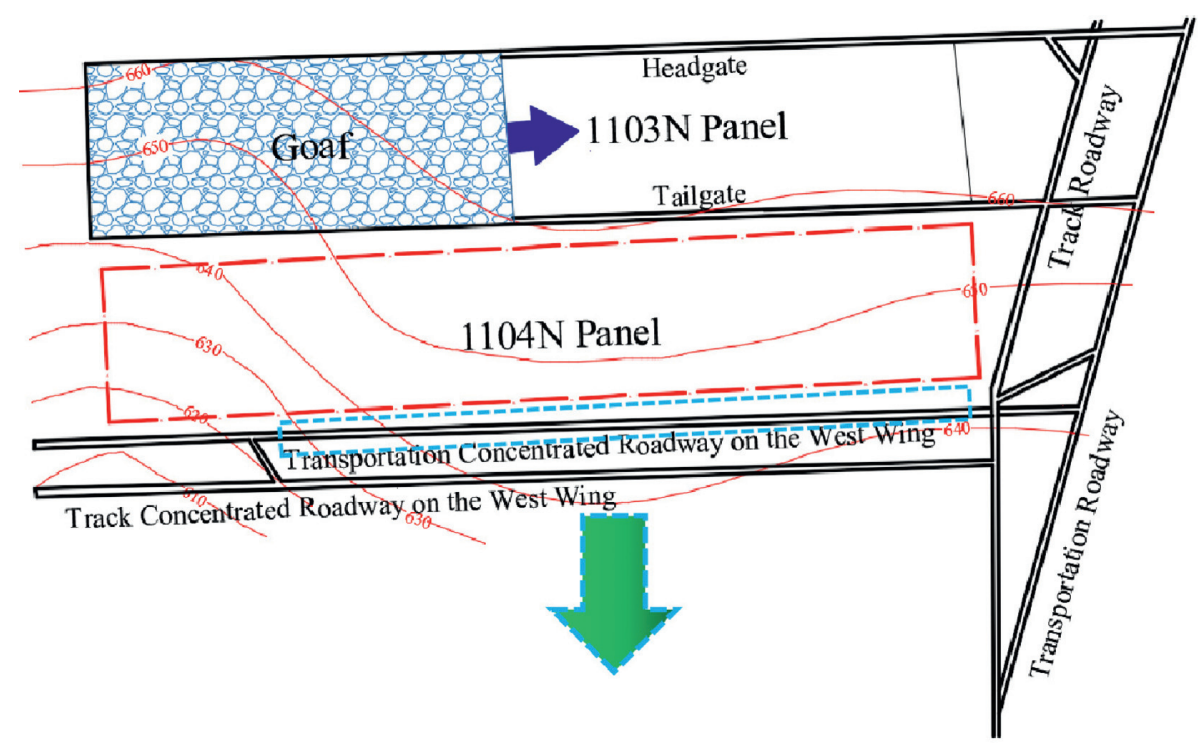

FIGURE 3: Location of TCRWW.

the bottom of the coal seam is relatively close, about 11 $\mathrm{m}-14.5 \mathrm{~m}$, and the water pressure is $0.3-0.8 \mathrm{MPa}$. The No. 5 and No. 6 coal seams above it have been recovered, and the accumulated water in the goaf area of the No. 6 coal seam has been drained during the No. 5 coal seam recovery process, which will not affect the recovery of the No. 1 coal seam. The water in the aquifer above and below No. 6 coal seam may become the water source of No. 5 coal water accumulation area after the No. 5 coal seam is recovered. It accumulates in the goaf of No. 5 coal seam, but it is located in the upper part of the no-coal area of No. 1 coal seam, which poses no threat to water recovery. During the mining of No. 1 coal seam, the water inflow is mainly the effluent from the austenitic aquifer in the floor. The maximum water inflow is $0.8 \mathrm{~m}^{3} /$ min and the normal water inflow is $0.4 \mathrm{~m}^{3} / \mathrm{min}$.

According to the on-site investigation, the rib-to-rib and the floor of TCRWW of Danhou Coal Mine have serious deformation (Figure 4). The deformation of the rib-to-rib of the roadway ranges from $0.4 \mathrm{~m}$ to $1.5 \mathrm{~m}$. In general, the floor heave is about $1 \mathrm{~m}$, the local floor heave can reach $1.2 \mathrm{~m}$, and the deformation is serious. The general floor heave is about $1 \mathrm{~m}$, and the local floor heave can reach $1.2 \mathrm{~m}$. To this end, the mine expands and reinforces the two sides of the roadway, and its deformation is controlled after the anchor cable is re-reinforced and supported. However, after a single excavation of the floor, the deformation of the floor heave reached about $1 \mathrm{~m}$ after more than ten days. It can be observed that simply removing the crushed rock in the roadway by excavating the floor will result in a larger area of weakened bearing capacity, thereby further weakening the overall bearing capacity of the roadway surrounding rock.

2.2. The Original Support Scheme of Roadway. The section of TCRWW is 4.6 wide by $3.2 \mathrm{~m}$ high, which is excavated along the No. 1 coal seam floor. The roof and ribs have a support structure, but the floor is opened without a support structure. The specific support parameters are as follows (Figure 5).
2.2.1. Roof Support Scheme. Anchor bolt: each row of the roof was installed with 6 bolts and a $4.4 \mathrm{~m} \mathrm{~W}$-shaped steel belt. The diameter and length of the roof anchor bolt were $20 \mathrm{~mm}$ and $2200 \mathrm{~mm}$, respectively. The bolt body was a right-handed, equal-strength rebar steel anchor bolt. The anchor bolt space of each row was $900 \mathrm{~mm}$. The space between two rows of the anchor bolt along the roadway length was $900 \mathrm{~mm}$. Each drill hole was filled with two K2850 resin anchoring agents. At the same time, an equal-strength iron tray and nut were utilized to match the anchor bolt, so that the pretightening force of the anchor bolt was not less than $70 \mathrm{kN}$. Anchor cable: each row of the roof was installed with 2 cables. The diameter and length of the roof anchor cable were $15.24 \mathrm{~mm}$ and $7000 \mathrm{~mm}$, respectively. The anchor cable uses a high-strength prestressed low-slack steel strand. The anchor cable space of each row was $1800 \mathrm{~mm}$. The space between two rows of the anchor cable along the roadway length was $1800 \mathrm{~mm}$. Each drill hole was filled with two MSCK23/120 two-speed resin anchoring agents. The pretightening force of the anchor cable was not less than $160 \mathrm{kN}$ (Figure 6). The metal mesh was made of No. 12 galvanized iron wire to cover the roof immediately.

2.2.2. Rib Support Scheme. Anchor bolt: each row of the rib was installed with 4 bolts and a $3 \mathrm{~m} \mathrm{~W}$-shaped steel belt. The diameter and length of the roof anchor bolt were $16 \mathrm{~mm}$ and $2200 \mathrm{~mm}$, respectively. The bolt body was a right-handed, equal-strength rebar steel anchor bolt. The anchor bolt space of each row was $900 \mathrm{~mm}$. The space between two rows of the anchor bolt along the roadway length was $900 \mathrm{~mm}$. Each drill hole was filled with two CK2530 resin anchoring agents. At the same time, an equal-strength iron tray and nut were utilized to match the anchor bolt, so that the pretightening force of the anchor bolt was not less than $50 \mathrm{kN}$. The metal mesh was made of No. 12 galvanized iron wire to cover the rib immediately. Reinforce anchor cables after deformation of the ribs: each row of the rib was installed with 2 cables. The 

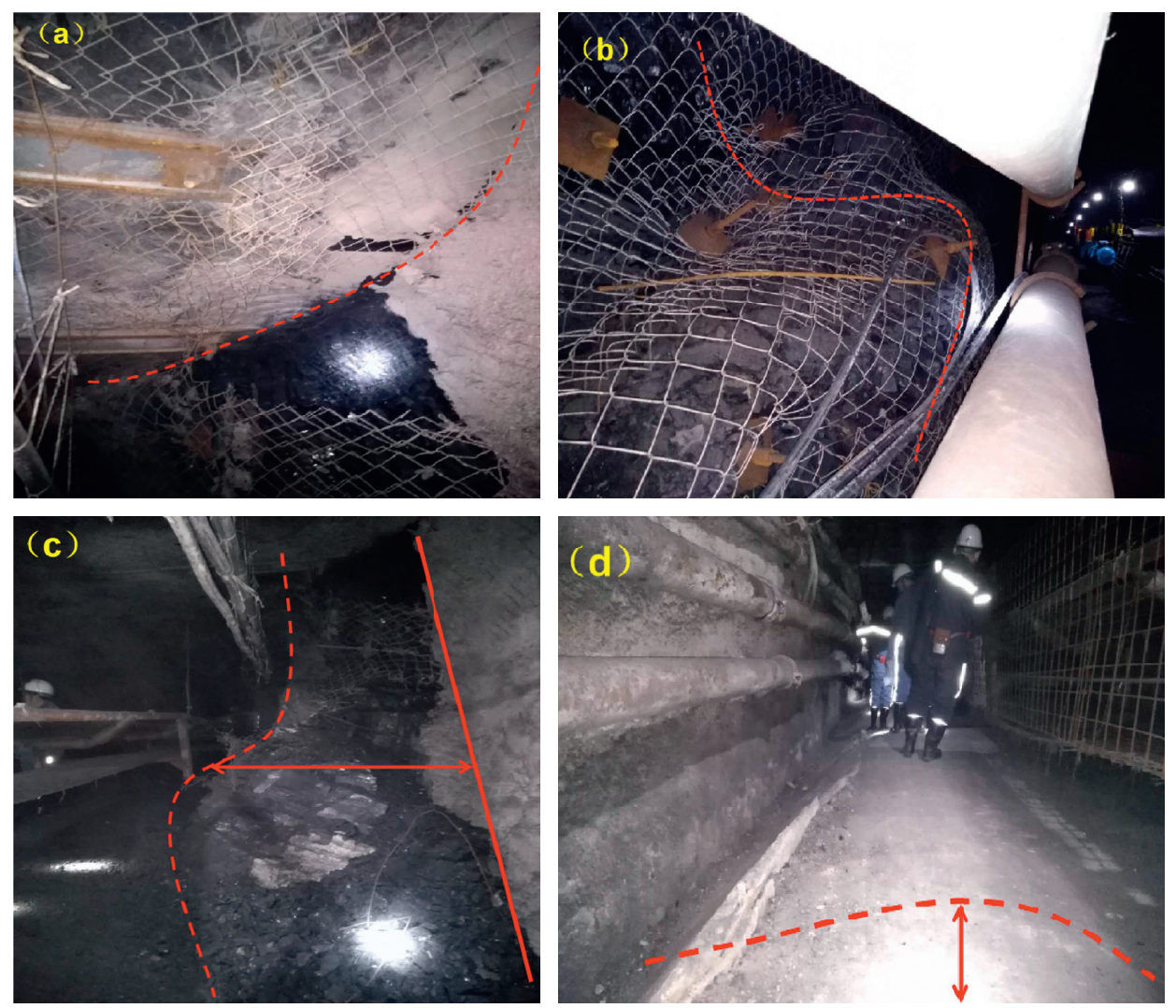

FIGURE 4: Failure pattern of TCRWW. (a) Deformation of the roof. (b) Deformation of the roadway-rib on the north side. (c) Deformation of the roadway-rib on the south side. (d) Floor heave.

diameter and length of the roof anchor cable were $15.24 \mathrm{~mm}$ and $4000 \mathrm{~mm}$, respectively. The anchor cable uses a highstrength prestressed low-slack steel strand. The anchor cable space of each row was $900 \mathrm{~mm}$. The space between two rows of the anchor cable along the roadway length was $900 \mathrm{~mm}$. Each drill hole was filled with two MSCK23/120 two-speed resin anchoring agents. The pretightening force of the anchor cable was not less than $100 \mathrm{kN}$ (Figure 7).

Therefore, taking into account the fact that the deformation of the floor heave of TCRWW is too large, it will seriously affect the normal mine production and transportation and safety assurance activities. In this paper, by studying the floor heave mechanism and prevention measures of TCRWW, a reasonable control scheme for roadway support parameters is obtained.

\section{Analysis of Floor Heave}

3.1. Analysis of Lithology and Structure of the Floor. Based on field investigation and analysis of geological data, it is concluded that the lithology of the floor of TCRWW is oolitic clay rock. After excavation of the roadway, enough space is provided for the deformation of the floor rock layer (Figure 8). With the long-term exposure of the floor of the roadway and the invasion of water, the phenomenon of muddling, disintegration, and rupture of the floor is obvious, and the strength of the floor rock layer decreases sharply [21-23].
Sampling and analysis of the chemical composition of the oolitic clay rock on the floor below the No. 1 coal seam yielded sample test results [24], as shown in Table 1 .

In the chemical quantitative analysis of the above 7 samples, the content of $\mathrm{SiO}$ was the highest, reaching $56.7 \%$ on average. Followed by $\mathrm{Al}_{2} \mathrm{O}_{2}$, the average content was $18.8 \%$. The average content of $\mathrm{Fe}_{2} \mathrm{O}_{2}$ was $8 \%$, and the content of other components was low. The composition of clay minerals on the floor of TCRWW is mainly kaolinite $(47 \%$ $57 \%)$, followed by illite $(15 \% \sim 35 \%)$ and illite-montmorillonite mixed-layer minerals $(17 \% \sim 28 \%)$.

Clay minerals, such as kaolinite and illite-montmorillonite mixed-layer minerals, have strong hydrophilicity due to their small particles and large specific surface area $[25,26]$. When water penetrates the pores and fissures in the floor rock layer, the adsorbed water film of the fine rock particles will thicken, causing the rock volume to expand. Because this volume expansion is nonuniform, it causes uneven stress in the rock, which causes the floor rock layer to be softened or dissolved, and eventually, a fragmented cracked body of rock particles is formed. The chemical reaction process is

$$
\begin{aligned}
& \mathrm{K}_{0.9} \mathrm{Al}_{2.9} \mathrm{Si}_{3.1} \mathrm{O}_{10}(\mathrm{OH})_{2}+n \mathrm{H}_{2} \mathrm{O} \longrightarrow \mathrm{K}_{0.9} \mathrm{Al}_{2.9} \mathrm{Si}_{3.1} \mathrm{O}_{10} \\
& \cdot(\mathrm{OH}) \cdot n \mathrm{H}_{2} \mathrm{O}
\end{aligned}
$$

The floor of TCRWW collapses and softens when it encounters water, which causes the floor of the roadway to 


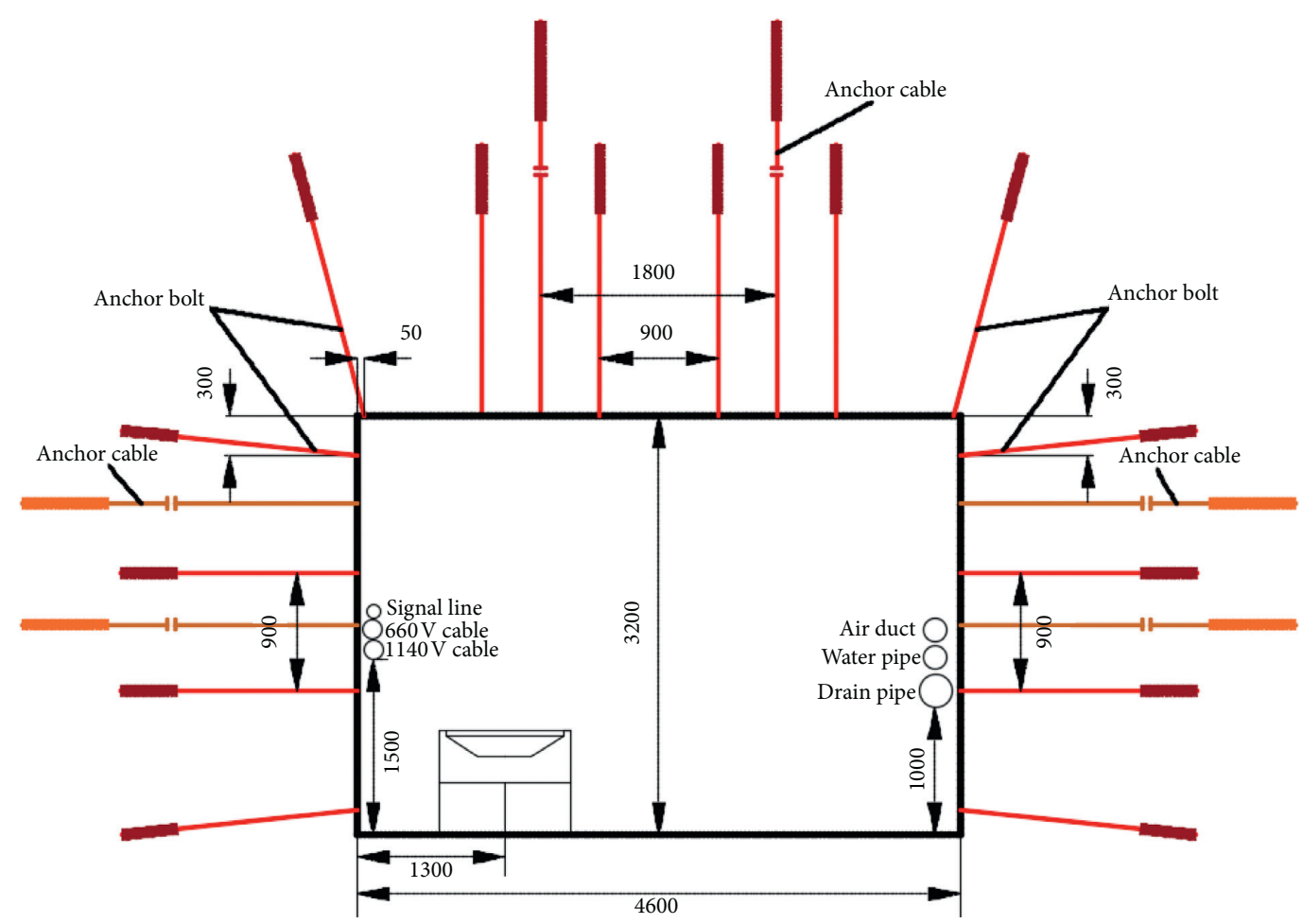

FIgURE 5: Original entry section supported by bolt and anchor cable.

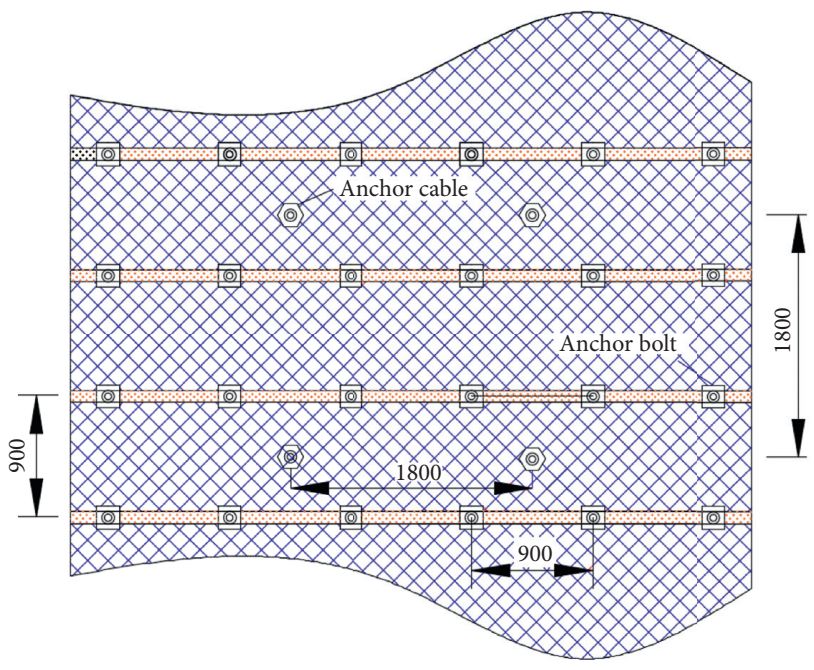

Figure 6: Supporting structure of the roof.

flood into the free space in the roadway, forming the bottom heave expansion deformation (the thickness of the adsorbed water film of the rock particles increases).

According to the analysis of the mineral composition of the rock layer of the roadway floor, it is shown that the mine production water and the water in the rock layer can easily penetrate the floor, weakening the bond between the rock particles and causing the rock particles to be damaged. This further causes the floor to soften, swell, and disintegrate, resulting in a large number of joints and cracks in the mudstone body of the floor, weakening the strength of the surrounding rock, resulting in the long-term overall stability of the surrounding rock.

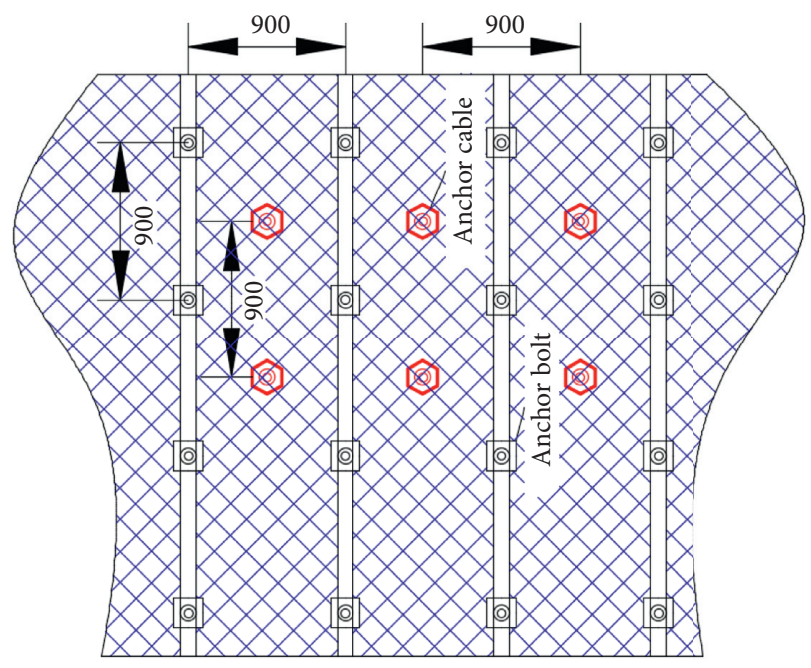

FIgURE 7: Supporting structure of the coal rib.

It can be observed that the change of the surrounding rock stress after the opening of TCRWW caused the elastoplastic deformation of the floor rock layer to unload and swell into the roadway. At the same time, the thick oolitic clay rock floor of TCRWW is subject to higher stress, which is dominated by horizontal stress. The thick oolitic clay rock floor contains kaolinite, illite, and other mineral components, which have strong water swelling properties. As a result, the compressive strength of the rock mass is greatly reduced, resulting in rheology and easy disturbance. At the same time, under the action of horizontal stress, the floor heave deformation is easier. 


\subsection{Deformation Mechanism of the Floor}

3.2.1. Establishment of the Mechanical Model of the Floor. The mining of No. 5 and No. 6 coal seams above No. 1 coal seam of Danhou Mine has been done, and the deformation of TCRWW is mainly affected by horizontal stress. Considering that the volume of roadway repairs caused by the roadway is sometimes even more than that of the newly excavated roadway, especially when the situation of repetitive problems occurs, the project volume is even greater. Therefore, it is imperative to study the underlying mechanism and control methods [27].

After excavation of TCRWW, supporting pressure concentration was formed on the roadway-rib (Figure 9). Under the combined action of support pressure and lateral deformation caused by mining and the horizontal stress $\left(F_{x}\right)$ of the floor rock layer along the layer direction, the floor heave of TCRWW has obvious deformation. When the horizontal stress $\left(F_{x}\right)$ on the floor rock layer exceeds the limit, it will cause instability of the floor rock layer (rock layer rupture and uplift). The deformation state of the floor rock layer under horizontal stress $\left(F_{x}\right)$ and gravity $(q)$ is shown in Figure 10 .

The bending equation is

$$
\frac{\mathrm{d}^{2} w}{\mathrm{~d} x^{2}}=-\frac{\mathrm{Mx}}{\mathrm{EJ}}
$$

then,

$$
\left\{\begin{array}{l}
\mathrm{Mx}=-F_{x A} x+M_{A}+\frac{q x^{2}}{2}+F_{x} w \\
q=m_{1} \gamma \\
J=\frac{\mathrm{Lh}^{3}}{12},
\end{array}\right.
$$

where $m_{1}$ is the thickness of the bending layer above the composite beam, $m$; $J$ is the bending section modulus of the upper part of the composite beam, $m^{4} ; \gamma$ is the bulk density of the rock layer, $\mathrm{MN} / \mathrm{m}^{3} ; E$ is the elastic modulus of the bending layer, $\mathrm{MPa} ; w$ is the amount of bending deformation, $m ; L$ is the span of TCRWW, $m$.

Therefore, simultaneous formulas (2) and (3) can be obtained:

$$
\frac{\mathrm{d}^{2} w}{\mathrm{~d} x^{2}}+\frac{F_{x}}{\mathrm{EJ}} w=-\frac{q}{2 \mathrm{EJ}}\left(x^{2}-\mathrm{Lx}+\frac{L^{2}}{6}\right) .
$$

Boundary conditions: $\left\{\begin{array}{l}\left.w\right|_{x=0}=0 \\ \mathrm{~d}^{2} w /\left.\mathrm{d} x\right|_{x=(1 / 2)}=0\end{array}\right.$.

If $k^{2}=\left(F_{x} / \mathrm{EJ}\right)$, getting the maximum bending tensile stress in the beam $(x=/ 2)$ can be obtained, and its magnitude is

$$
\begin{aligned}
\sigma_{\max }= & -\frac{\gamma L^{2}}{4 m_{1}}+\frac{6 \gamma}{m_{1} k^{2}}\left[\left(\frac{L^{2} k^{2}}{12}-1\right) \sec \left(\frac{\mathrm{kL}}{2}\right)+\left(\frac{k^{2} L^{2}}{24}+1\right)\right] \\
& -F_{x} m_{1} .
\end{aligned}
$$

The second part of formula (5) is an additional term when the horizontal stress is $F_{x}$. $\sec \left(\mathrm{kL}^{2} / 2\right)$ in the formula is infinite when the following formula is satisfied:

$$
\frac{\mathrm{kL}}{2}=\left(\frac{1}{2}+n\right) \pi, \quad n=0,1,2 \ldots
$$

At this time, $\left.\sigma\right|_{x=1 / 2} \longrightarrow \infty$, and the beam loses its ability to resist the horizontal stress $F_{x}$, which causes instability and damage, and the minimum axial force $F_{x C}$ (i.e., $F_{x}$ at $\left.n=0\right)$ is

$$
F_{\mathrm{xC}}=\frac{\pi^{2} \mathrm{EJ}}{L^{2}} \text {. }
$$

3.2.2. Factors Affecting Floor Stability of Layered Rock Strata. According to the above analysis, the critical axial force of the instability and failure of the floor is $F_{\mathrm{xC}}=\left(\pi^{2} \mathrm{EJ} / L^{2}\right)$ (the influence of the roadway height is not considered here). Assuming that the lateral pressure coefficient of the floor under the concentrated support pressure is $\lambda$ and the maximum supporting force around it is $K \gamma H$, the horizontal force on the floor rock formation can be approximated as

$$
F_{x}=\lambda K \gamma H
$$

When $F_{x} \geq F_{\mathrm{xC}}$, the instability of the floor rock layer occurs. Substitute $F_{\mathrm{xC}}$ into this formula and simplify it to get the following formula:

$$
\frac{\mathrm{KHL}}{\mathrm{Em}_{1}^{3}} \geq \frac{\pi^{2}}{12 \gamma \lambda}
$$

It can be seen from the above formula that the deeper the horizon and the larger the span, the lower the strength of the floor rock layer, and the smaller the thickness of the layer, the more prone to instability and damage. Among them, the effect of layer thickness $m_{1}$ is the most obvious, followed by the span $L$ of the roadway and the influence of the mining depth $H$, and the elastic mode $E$ is the smallest.

Considering that the mining depth and floor lithology in the coal seam are fixed, and the roadway has been excavated and the span $L$ of TCRWW cannot be adjusted. Therefore, the layer thickness $m_{1}$ can only be raised by anchoring the floor, which can effectively control the deformation of the floor and ensure the stability of TCRWW.

\section{Model Establishment}

4.1. Model Parameter Determination. In the process of modeling TCRWW, the initial equilibrium stage of the model adopts the equivalent $\mathrm{M}-\mathrm{C}$ criterion parameters of the rock mass obtained by the $\mathrm{H}-\mathrm{B}$ criterion (Table 2) [28]. However, considering that after the excavation of TCRWW, the floor collapsed and softened, and the strength decreased rapidly or even lost the bearing capacity. If the classic elastoplastic model is used for calculation after the excavation, the calculation results will not fully meet the basic characteristics of rock deformation. Therefore, after the 


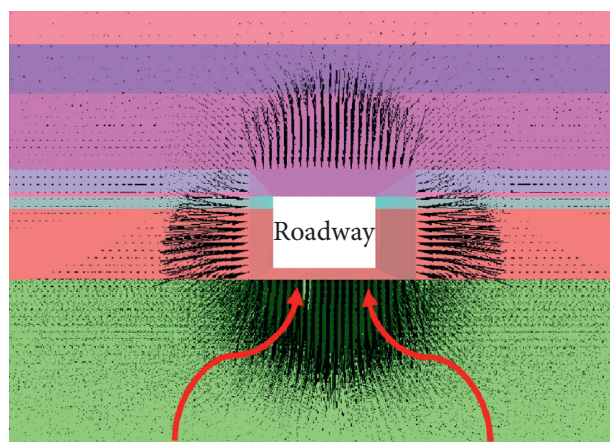

(a)

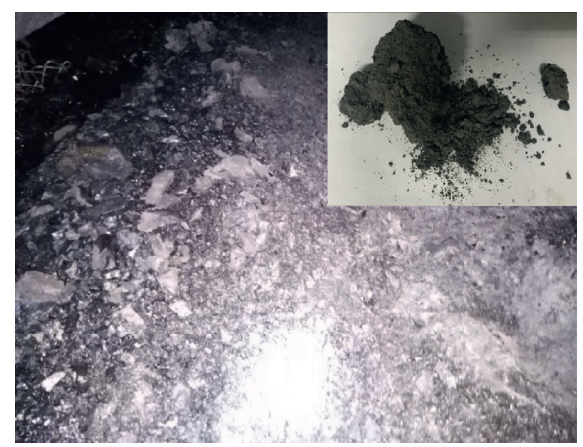

(b)

FIGURE 8: Deformation state and lithology of the floor. (a) Displacement of TCRWW. (b) Floor of the oolitic clay rock.

TABLE 1: Quantitative analysis of the chemical composition of bottom rock formations (\%).

\begin{tabular}{lcccccccccc}
\hline Sample & $\mathrm{SiO}_{2}$ & $\mathrm{Al}_{2} \mathrm{O}_{2}$ & $\mathrm{Fe}_{2} \mathrm{O}_{2}$ & $\mathrm{FeO}$ & $\mathrm{Fe}_{2} \mathrm{O}_{2} / \mathrm{FeO}$ & $\mathrm{CaO}$ & $\mathrm{MgO}$ & $\mathrm{K}_{2} \mathrm{O}$ & $\mathrm{Na}_{2} \mathrm{O}$ & $\mathrm{TiO}_{2}$ \\
\hline 1 & 55.54 & 17.71 & 12.81 & 0.86 & 14.89 & 0.23 & 0.40 & 1.02 & 0.02 & 1.37 \\
2 & 61.23 & 15.74 & 5.05 & 0.95 & 5.32 & 0.30 & 0.94 & 1.23 & 0.09 & 1.80 \\
3 & 46.81 & 17.38 & 1.75 & 10.24 & 0.17 & 1.26 & 0.87 & 1.61 & 0.07 & 1.58 \\
4 & 53.62 & 29.03 & 1.22 & 0.18 & 6.78 & 0.36 & 0.45 & -2. & -- & 1.59 \\
5 & 66.70 & 16.04 & 13.36 & 0.18 & 74.22 & 0.17 & 0.26 & 2.49 & 0.09 & 1.59 \\
6 & 53.23 & 20.93 & 10.53 & 0.18 & 58.50 & 0.17 & 1.03 & 2.29 & 0.06 \\
7 & 60.03 & 14.86 & 12.63 & 0.18 & 70.17 & 0.06 & 1.11 & 2.06 & 0.11 \\
\hline
\end{tabular}

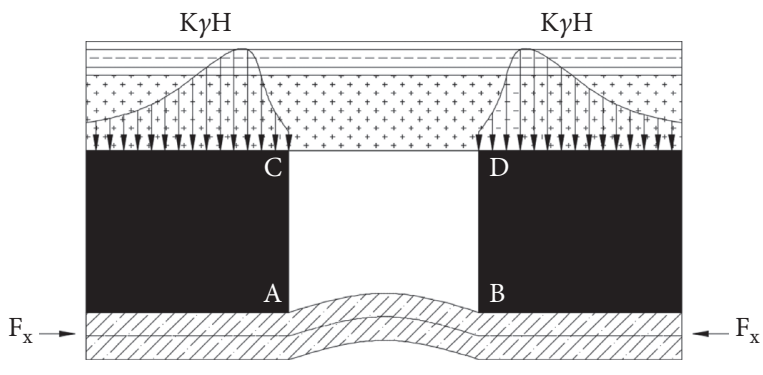

FIgURE 9: Stress state of TCRWW.

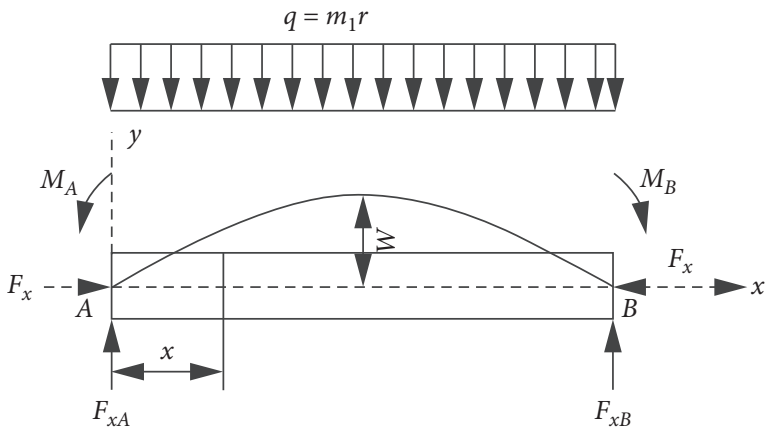

FIgURE 10: Mechanical model of the floor.

excavation of TCRWW, the floor is parameterized as a strain-softening model parameter. The model criterion is based on the Mohr-Coulomb criterion. The difference is that the built-in table can be used as a parameter to control the cohesion, internal friction angle, tensile strength, and crushing angle of the rock mass after failure. So that it will decrease with the increase of plastic shear strain and reduce the strength of the rock mass.

4.2. Model Establishment. According to the geological conditions of the coal belt and the mechanical parameters of TCRWW of Danhou Mine, numerical modeling was performed using FLAC3D numerical simulation software. The model has a dimension of $100 \mathrm{~m} \times 68.4 \mathrm{~m} \times 10 \mathrm{~m}$ (length $\times$ width $\times$ height), as shown in Figure 11. TCRWW is located in the middle of the coal seam and excavated according to its actual section of $4.6 \mathrm{~m} \times 3.2 \mathrm{~m}$ (length$\times$ height). The overall model is composed of 223,440 units and 248,039 nodes, and the grid size gradually increases outward from TCRWW. The simulation was performed using the Mohr-Coulomb criterion, and parameters were assigned to each rock formation according to the mechanical parameters shown in Table 2. According to the thickness of the coal seam being $400 \mathrm{~m}$, a corresponding vertical downward pressure of $10 \mathrm{MPa}$ is applied to the top of the model to simulate the weight of the unbuilt rock. The vertical displacement at the bottom of the model is constrained, and the lateral displacement at the front, back, left, and right directions of the model is constrained.

4.3. Deformation of TCRWW. (1) Shown in Figure 12(a) is the horizontal stress distribution after extraction of TCRWW and under the roadway support structure. A green compressive stress zone is formed in the coal ribs of 
TABLE 2: Rock strata properties used in numerical modeling.

\begin{tabular}{|c|c|c|c|c|c|c|c|c|c|}
\hline Lithology & $\mathrm{M}(\mathrm{m})$ & $\mathrm{P}\left(\mathrm{kg} / \mathrm{m}^{3}\right)$ & $E(\mathrm{GPa})$ & $v$ & $K(\mathrm{GPa})$ & $G(\mathrm{GPa})$ & $t(\mathrm{MPa})$ & $c(\mathrm{MPa})$ & $\Phi\left(^{\circ}\right)$ \\
\hline Mudstone & 4.4 & 2550 & 0.68476 & 0.2 & 0.380 & 0.285 & 0.062 & 0.773 & 14.89 \\
\hline Siltstone & 5.6 & 2540 & 0.90151 & 0.22 & 0.537 & 0.369 & 0.0235 & 1.335 & 22.29 \\
\hline Mudstone & 1.4 & 2550 & 1.56048 & 0.2 & 0.867 & 0.650 & 0.1557 & 1.109 & 19.87 \\
\hline No. 4 coal & 1.1 & 1400 & 2.88938 & 0.25 & 1.926 & 1.156 & 0.1648 & 1.36 & 26.87 \\
\hline Carbonaceous mudstone & 16 & 2550 & 2.50571 & 0.23 & 1.547 & 1.019 & 0.2249 & 1.244 & 23.06 \\
\hline Siltstone & 2.2 & 2540 & 2.93616 & 0.22 & 1.748 & 1.203 & 0.0604 & 1.72 & 27.58 \\
\hline Mudstone & 4.6 & 2550 & 3.2031 & 0.2 & 1.780 & 1.335 & 0.2529 & 1.301 & 22.49 \\
\hline Siltstone & 0.6 & 2540 & 5.49104 & 0.22 & 3.268 & 2.250 & 0.1285 & 2.028 & 30.5 \\
\hline No. 1 coal & 3.2 & 1400 & 2.44968 & 0.25 & 1.633 & 0.980 & 0.1681 & 1.407 & 27.67 \\
\hline Oolitic clay rock & 9.3 & 2550 & 1.95694 & 0.2 & 1.087 & 0.815 & 0.1384 & 1.201 & 21.77 \\
\hline Limestone & 20 & 2100 & 4.03721 & 0.29 & 3.204 & 1.565 & 0.1133 & 3.224 & 27.58 \\
\hline
\end{tabular}

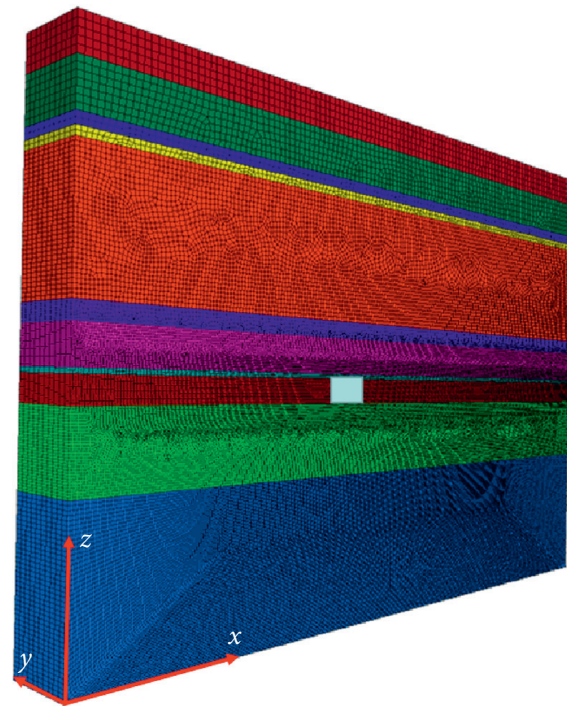

Figure 11: Numerical simulation model.

TCRWW. The stress field range is about $2 \mathrm{~m}$ and the overall size is $0.4 \mathrm{MPa}$. The stress in the middle compressive stress area is the largest, which is about $0.9 \mathrm{MPa}$. From the overall shape and stress distribution, the dark blue compressive stress area in the middle of the support stress field formed by the coal ribs of TCRWW under the original support scheme overlaps with the outer green compressive stress zone and is connected with the stress zone generated by the anchor bolts at the uppermost part of TCRWW. However, there is a part of the low-stress area between the floor without support members and the anchor bolts at the lower part of coal ribs, so the support stress field of the original support scheme cannot control the floor heave. (2) As shown in Figure 12(b), a large and continuous green compressive stress area is formed in the roof of TCRWW. The stress field range is about $2 \mathrm{~m}$, the overall size is $0.25 \mathrm{MPa}$, and the maximum stress value in the compressive stress area is about $0.6 \mathrm{MPa}$. From the perspective of roof support, the vertical stress field of the roof of TCRWW can be effectively applied to the overhanging rock mass due to the superposition of the support stress fields of roof and ribs, verifying that the roof is relatively complete under the condition of the original roadway support live situation. Compared with the roof, the floor is only supported by the two inclined anchor bolts of coal ribs. Although it has a certain supporting effect on the floor corners, it lacks the supporting means for the floor. Therefore, the support stress fields cannot be connected, and most of the rock mass of the floor is in a tension state, which makes it difficult to control the floor heave. (3) As shown in Figure 12(c), the deformation of the roof and the coal ribs of TCRWW is about $0.5 \mathrm{~m}$, and the maximum deformation of the floor is about $1.3 \mathrm{~m}$. (4) As shown in Figure 12(d), under the condition of the original support scheme, due to the large difference between the maximum and minimum principal stresses of TCRWW, the overall yield area of TCRWW showed an " $X$ "-type failure. The damage depth of the coal ribs is $2.4 \mathrm{~m}$, the damage depth of the roof is $4.5 \mathrm{~m}$, and the damage depth of the floor is $8.8 \mathrm{~m}$. However, there is a large range of yield areas on the floor, and the yield area extends outward along the direction of an angle of about $45^{\circ}$. At the same time, due to the lack of support measures for the floor, large-scale floor damage and water disintegration will inevitably lead to large deformation.

To sum up, the deformation phenomenon of the surrounding rock of TCRWW reflected in the numerical simulation is consistent with the field measurement of displacements of the roof-to-floor and rib-to-rib. At the same time, it can be seen that the floor heave deformation caused by the unsupported members of the floor is relatively obvious.

\section{Engineering Application}

5.1. Floor Heave Control Technology of TCRWW. Based on the actual geological conditions of the Danhou Mine and relevant supporting schemes [29], the main support parameter of TCRWW is shown in Table 3, and the support method is shown in Figure 13. The floor of TCRWW was excavated to form a downward arc-shaped space $800 \mathrm{~mm}$ away from the center of the floor, and the deformation pressure of the deep rock mass was released by overexcavating the floor. (2) $50 \mathrm{~mm}$ quicklime was evenly laid on the bottom of the arc-shaped space as a water barrier to prevent the mine water inside the roadway from penetrating the floor rock layer and reducing the floor strength. (3) Place the precast concrete arc beam in it, and lay a metal mesh (No. 12 iron wire braid). The diameter and length of the floor anchor cables were $15.24 \mathrm{~mm}$ and $6000 \mathrm{~mm}$, respectively. 


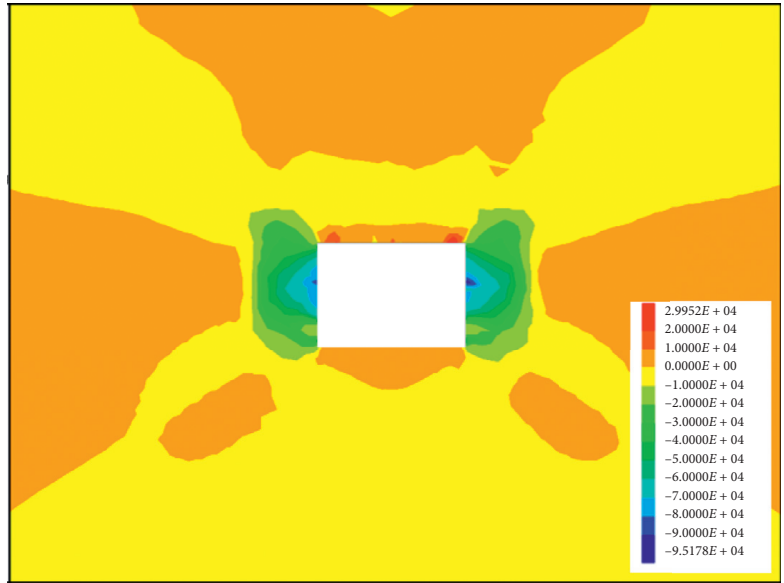

(a)

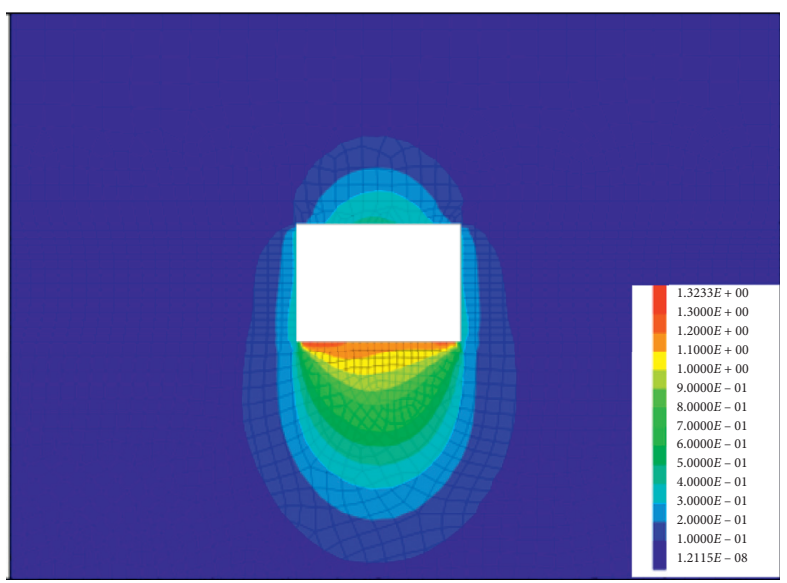

(c)

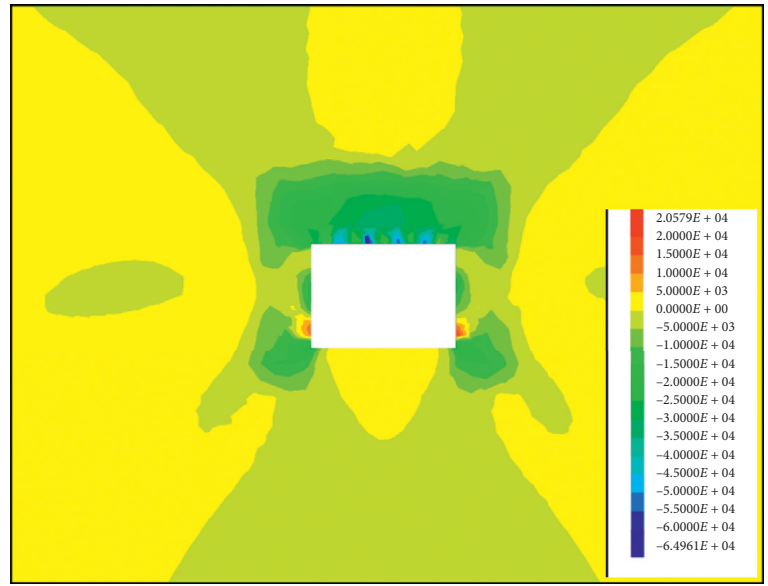

(b)

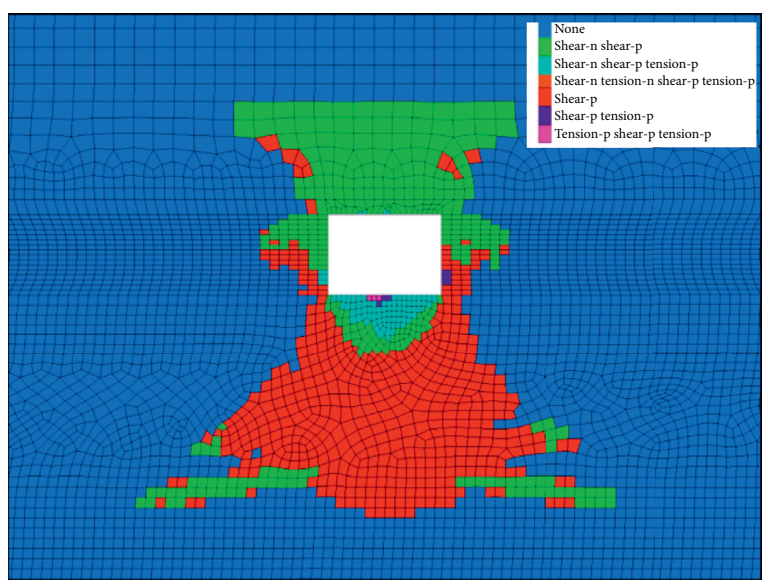

(d)

FiguRE 12: Stress distribution and yield elements after extraction of TCRWW. (a) Horizontal stress. (b) Vertical stress. (c) Displacement. (d) Yield elements.

TABLE 3: Support parameters of TCRWW.

\begin{tabular}{|c|c|c|c|c|c|}
\hline \multirow[b]{2}{*}{ Location } & \multirow[b]{2}{*}{$\begin{array}{l}\text { Support } \\
\text { members }\end{array}$} & \multicolumn{4}{|c|}{ Support parameters } \\
\hline & & Spacing between rows $(\mathrm{mm} \times \mathrm{mm})$ & $\begin{array}{c}\text { Type } \\
(\mathrm{mm} \times \mathrm{mm})\end{array}$ & $\begin{array}{l}\text { Minimum } \\
\text { pretightening force } \\
(\mathrm{kN})\end{array}$ & Material \\
\hline \multirow[b]{2}{*}{ Roof } & Anchor bolt & $900 \times 900$ & $\varphi 20 \times 2200$ & 70 & $\begin{array}{l}\text { Right-handed rebar } \\
\text { without longitudinal } \\
\text { bars }\end{array}$ \\
\hline & Anchor cable & $1800 \times 1800$ & $\varphi 15.24 \times 7000$ & 160 & $\begin{array}{l}\text { High-strength } \\
\text { pretightening low-slack } \\
\text { steel strand }\end{array}$ \\
\hline \multirow{2}{*}{ Rib } & Anchor bolt & $900 \times 900$ & $\varphi 16 \times 2000$ & 50 & $\begin{array}{l}\text { Right-handed rebar } \\
\text { without longitudinal } \\
\text { bars }\end{array}$ \\
\hline & Anchor cable & $1600 \times 1600$ & $\varphi 15.24 \times 3000$ & 100 & $\begin{array}{l}\text { High-strength } \\
\text { pretightening low-slack } \\
\text { steel strand }\end{array}$ \\
\hline \multirow{2}{*}{ Floor } & Anchor cable & $1600 \times 2000$ & $\varphi 15.24 \times 6000$ & 100 & $\begin{array}{l}\text { High-strength } \\
\text { pretightening low-slack } \\
\text { steel strand }\end{array}$ \\
\hline & $\begin{array}{l}\text { Antifloor } \\
\text { arch } \\
\text { structure }\end{array}$ & $\begin{array}{l}\text { Quicklime bottom paving + prestressed anchor } \\
\text { cable + concrete arc beam }+ \text { metal mesh }+ \text { C20 } \\
\text { high-strength concrete filling }\end{array}$ & & & \\
\hline
\end{tabular}




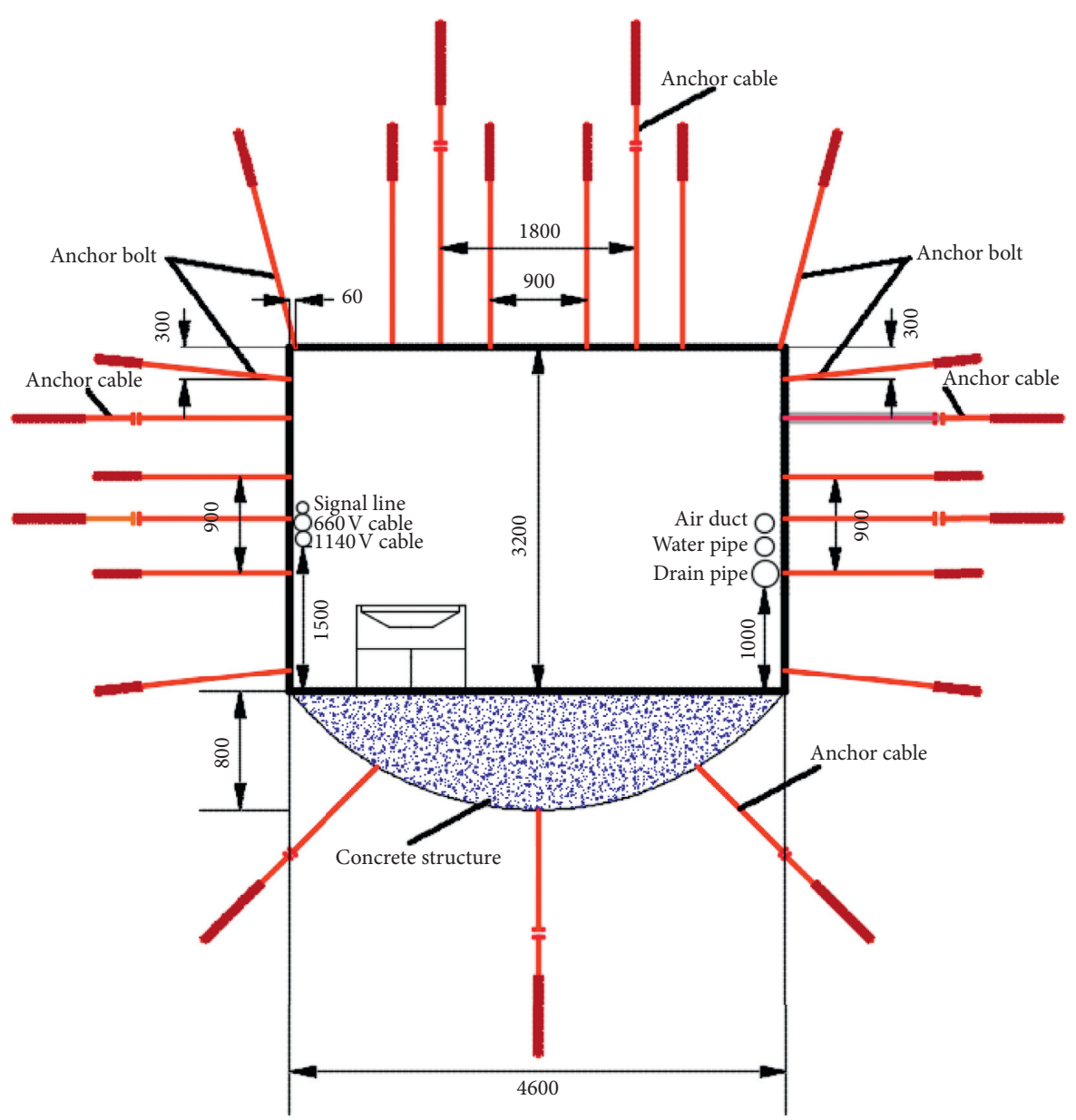

(a)

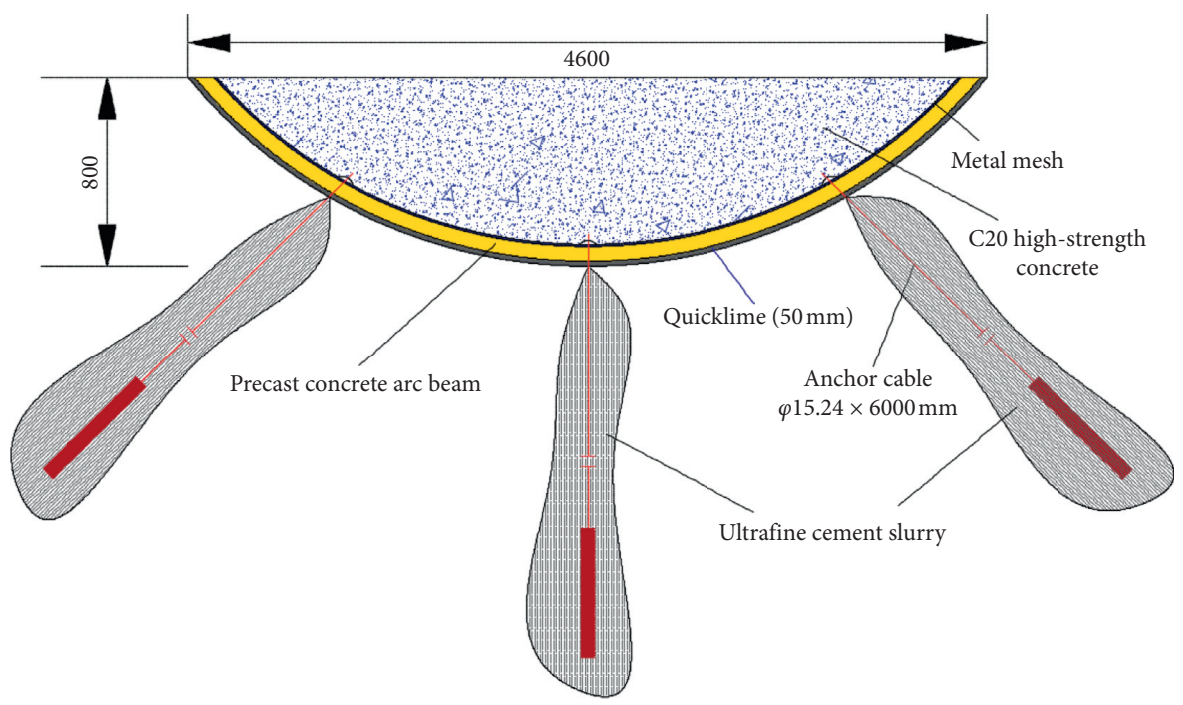

(b)

FIgURE 13: Support scheme of TCRWW. (a) Roadway section. (b) Antifloor arch structure.

The anchor cable space of each row was $1600 \mathrm{~mm}$. The space between two rows of the anchor cable along the roadway length was $2000 \mathrm{~mm}$. Each drill hole was filled with an ultrafine cement slurry with a water-cement ratio of $0.8: 1$. The pretightening force of the anchor cable was not less than
$100 \mathrm{kN}$. (4) C20 high-strength concrete was used to backfill the arc-shaped space at the overexcavation to keep the floor flat.

Through the above methods, the mechanical properties and stress state of the direct force receiving body of the floor 


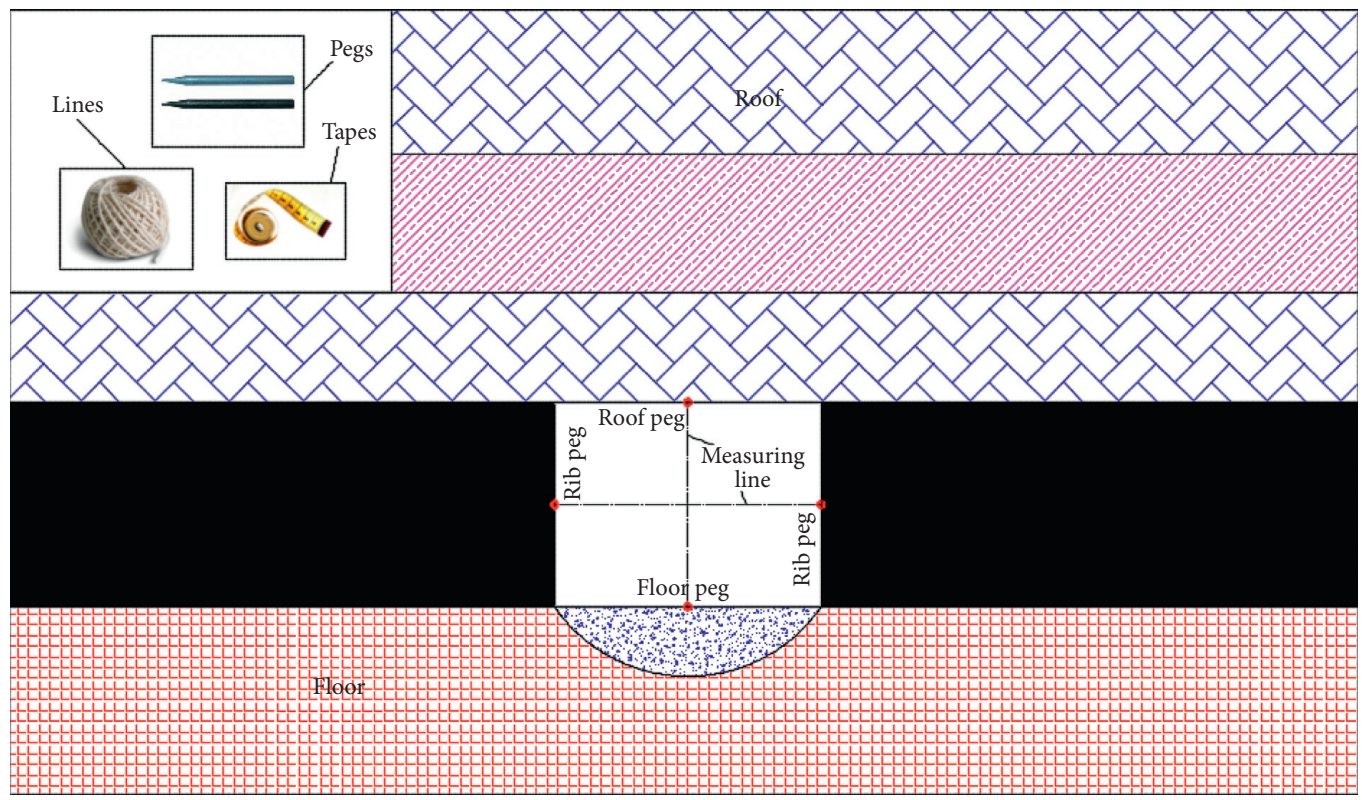

FIGURE 14: Layout of the measurement station.

are improved, and the deformation resistance of the floor and the ribs is improved. Among them, the support parameters of the roof and the ribs of TCRWW are unchanged, and the support parameters are only formulated for the floor.

5.2. Instrumentation Results and Analysis. According to the geological conditions of Danhou Mine, the mechanism and control technology of the floor heave are analyzed. At the same time, the floor heave treatment plan for the $100 \mathrm{~m}$ roadway test section was formulated. Based on retaining the support conditions of the roof and the ribs, there is the technology of adding an antifloor arch structure and combining water control measures to achieve effective control of the floor. After adopting the floor control scheme in the test roadway, four surface displacement measuring stations were set up in the test section to monitor the convergence of the roof-to-floor and the rib-to-rib of TCRWW (Figure 14).

The analysis of the convergence data of TCRWW in station 2 is shown in Figure 15. The change of the surface displacement of TCRWW in the test section can be divided into 3 stages. (1) The stage of rapid convergence of TCRWW is 6 to 22 days after the roadway is repaired. The convergence at this stage accounts for about $70 \%$ of the total convergence. (2) From 23 to 42 days after TCRWW was repaired, the convergence rate at this stage gradually decreases and stabilizes; after 42 days of TCRWW repair, the convergence of the surrounding rock of the roadway stabilizes. (3) After TCRWW has been repaired for 60 days, the final floor heave of TCRWW in the test section was $62.5 \mathrm{~mm}$, the maximum convergence of the rib-to-rib was $152 \mathrm{~mm}$, and the maximum roof subsidence was $122 \mathrm{~mm}$.

Overall, the new support scheme of TCRWW has a significant effect on the control of the floor heave and the

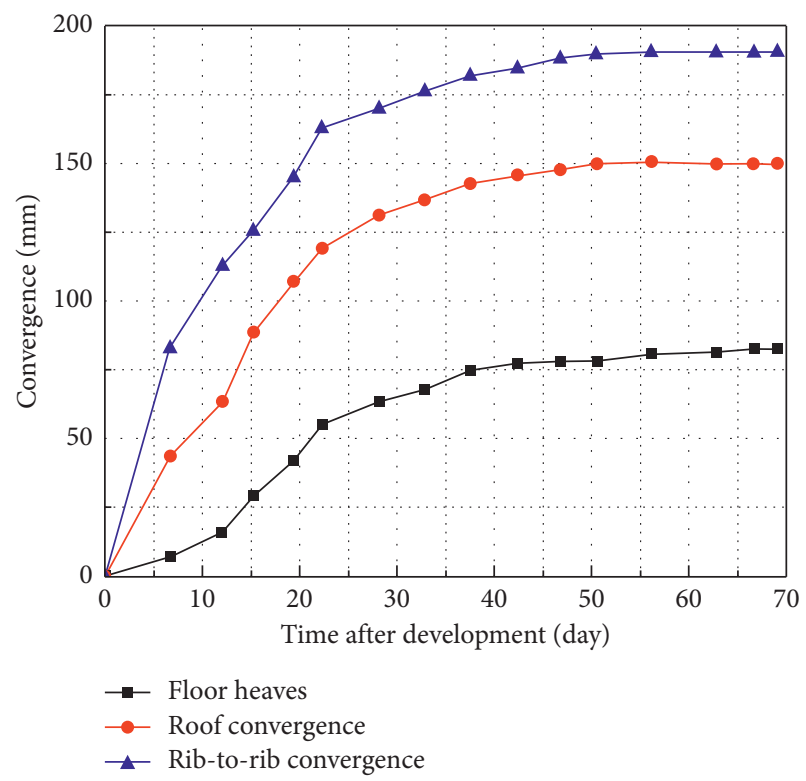

FIGURE 15: Displacement-time curve of station 2.

approach of the ribs. Its convergence amount meets the safety production requirements of the panel and can maintain stability for a long time. At the same time, the normal transportation of coal was ensured, and good engineering results were achieved.

\section{Conclusion}

Given the serious deformation of TCRWW of No. 1 Coal Seam in Danhou Mine, it is impossible to guarantee the safe production of the mine. It can be seen that simply removing the crushed rock in TCRWW by excavating the floor will result in a larger area of weakened bearing capacity, thereby further weakening the overall bearing capacity of TCRWW. 
(1) The floor of TCRWW was sampled and analyzed, and the clay mineral content was determined. The composition of clay minerals is mainly kaolinite (47\% 57\%), followed by illite (15\% 35\%) and illitemontmorillonite mixed-layer minerals (17\% 28\%). Because the abovementioned clay minerals are very hydrophilic, uneven stresses are generated in the rocks. As a result, the floor rock layer is softened to form a fragmented fragment of rock particles, which greatly reduces its compressive strength.

(2) By analyzing the mechanical model of the floor of TCRWW, the deeper the level of the roadway and the larger the span, the lower the strength of the floor rock layer, and the smaller the thickness of the layer, the more likely it is that the roadway will be unstable. Therefore, the layer thickness $m_{1}$ can only be raised by anchoring the floor, which can effectively control the deformation of the floor and ensure the stability of TCRWW.

(3) Using Flac3D numerical simulation to analyze the change of TCRWW under the original support parameters. According to the deformation characteristics of surrounding rock reflected in the vertical stress, horizontal stress, displacement, and yield elements of TCRWW, it can be seen that the floor heave deformation caused by the unsupported members of the floor is obvious.

(4) Based on the original support parameters of TCRWW, the antifloor arch structure was proposed: "quicklime bottom paving + prestressed anchor cable + concrete arc beam + metal mesh + C20 highstrength concrete filling." It is used to improve the mechanical properties and stress state of the direct force body of the floor and improve its resistance to deformation.

(5) The $100 \mathrm{~m}$ test roadway floor treatment for TCRWW in Danhou Mine was carried out. By monitoring the convergence of the surrounding rock of the test roadway, the new support scheme effectively controlled the convergence of the floor and ribs. The final floor heave amount of TCRWW is $62.5 \mathrm{~mm}$, and its convergence meets the requirements of mine safety production.

\section{Data Availability}

The data used to support the findings of this study are available from the corresponding author upon request.

\section{Conflicts of Interest}

The authors declare that they have no conflicts of interest.

\section{Acknowledgments}

The authors gratefully acknowledge the support of the National Natural Science Foundation of Surface Project of China (no. 51774289) and the School-Level Scientific
Research Project of Shanxi Institute of Technology (no. 2018006).

\section{References}

[1] H. W. Huang and P. Che, "Research on micro-mechanism of softening and argillitization of mudstone," Journal of Tongji University (Natural Science), vol. 35, no. 7, pp. 866-870, 2007.

[2] Z. F. Chu, Z. J. Wu, B. G. Liu et al., "Coupled analytical solutions for deep-buried circular lined tunnels considering tunnel face advancement and soft rock rheology effects," Tunnelling and Underground Space Technology, vol. 94, no. 12, pp. 103-111, 2019.

[3] L. Sun, H. Wu, B. Yang, and Q. Li, "Support failure of a highstress soft-rock roadway in deep coal mine and the equalized yielding support technology: a case study:a case study," International Journal of Coal Science \& Technology, vol. 2, no. 4, pp. 279-286, 2015.

[4] Z. Guo, Z. Du, S. Hu, X. Zhang, K. Wang, and J. Guo, "Comprehensive treatment methods of floor heave disasters in mining areas of China," Geotechnical and Geological Engineering, vol. 35, no. 5, pp. 2485-2495, 2017.

[5] G. Li, F. S. Ma, J. Guo et al., "Study on deformation failure mechanism and support technology of deep soft rock roadway," Engineering Geology, vol. 264, no. 1, pp. 1-15, 2020.

[6] Y. L. Xu, K. R. Pan, and H. Zhang, "Investigation of key techniques on floor roadway support under the impacts of superimposed mining: theoretical analysis and field study," Environmental Earth Sciences, vol. 78, no. 7, pp. 436-450, 2019.

[7] H. Einstein, "Suggested methods for laboratory testing of argillaceous swelling rocks," International Journal of Rock Mechanics Mining Sciences and Geomechanics Abstracts, vol. 26, no. 5, pp. 415-426, 1989.

[8] J. Yang, K. Zhou, Y. Cheng, Y. Gao, Q. Wei, and Y. Hu, "Mechanism and control of roadway floor heave in the paleogene soft rock surroundings," Geotechnical and Geological Engineering, vol. 37, no. 6, pp. 5167-5185, 2019.

[9] Y. D. Jiang and S. L. Lu, "Investigation of mechanism of floor heave," Journal of China Coal Society, vol. 19, no. 4, pp. 345-351, 1994.

[10] Y. D. Jiang, Y. X. Zhao, W. G. Liu et al., "Research on floor heaving of roadway in deep mining," Chinese Journal of Rock Mechanics and Engineering, vol. 23, no. 14, pp. 2396-2401, 2004.

[11] H. Q. Zhang, L. J. Han, Y. G. He et al., "Floor heave control in roadways with soft-and-swelling rocks in complicated structural area," Journal of Mining and Safety Engineering, vol. 28, no. 1, pp. 16-21, 2011.

[12] R. Seedsman, "The behaviour of clay shales in water," $\mathrm{Ca}$ nadian Geotechnical Journal, vol. 23, no. 1, pp. 18-22, 1986.

[13] D. Xu, S. Peng, S. Xiang, M. Liang, and W. Liu, "The effects of caving of a coal mine's immediate roof on floor strata failure and water inrush," Mine Water and the Environment, vol. 35, no. 3, pp. 337-349, 2016.

[14] W. J. Wang, S. Q. Li, and G. B. Ouyang, "Study on technique and test of surrounding rock control of deep shaft coal roadway," Chinese Journal of Rock Mechanics and Engineering, vol. 25, no. 10, pp. 2102-2107, 2016.

[15] H. Jia, L. Wang, K. Fan, B. Peng, and K. Pan, "Control technology of soft rock floor in mining roadway with coal pillar protection: a case study," Energies, vol. 12, no. 15, pp. 3009-3030, 2019. 
[16] G. X. Xie and J. C. Chang, "Study on overcutting-bolting \& grouting-backfilling concrete to control the floor heave of deep mine roadway," Journal of China Coal Society, vol. 35, no. 8, pp. 1242-1246, 2010.

[17] J. Zheng, Y. Guo, C. Feng, and H. Chen, "A hierarchical neural-network-based document representation approach for text classification," Mathematical Problems in Engineering, vol. 2018, no. 10, Article ID 3545423, 14 pages, 2018.

[18] M. C. He, G. F. Zhang, G. L. Wang et al., "Research on mechanism and application to floor heave control of deep gateway," Chinese Journal of Rock Mechanics and Engineering, vol. 28, no. S1, pp. 2593-2598, 2019.

[19] B. X. Huang, Q. Y. Cheng, X. L. Zhao et al., "Using hydraulic fracturing to control caving of the hanging roof during the initial mining stages in a longwall coal mine: a case study," Arabian Journal of Geosciences, vol. 11, no. 10, pp. 603-619, 2018.

[20] B. X. Huang, X. L. Zhao, and J. Ma, "Field experiment of destress hydraulic fracturing for controlling the large deformation of the dynamic pressure entry heading adjacent to the advancing longwall face," Archives Of Mining Sciences, vol. 64, no. 4, pp. 829-848, 2019.

[21] J. G. Kan, N. Zhang, G. C. Li et al., "Floor controlling technology of argillization roadway," Journal of Mining \& Safety Engineering, vol. 28, no. 3, pp. 356-360, 2011.

[22] W. Yu, B. Pan, F. Zhang, S. Yao, and F. Liu, "Deformation characteristics and determination of optimum supporting time of alteration rock mass in deep mine," KSCE Journal of Civil Engineering, vol. 23, no. 11, pp. 4921-4932, 2019.

[23] P. Wang, H. Jia, and P. Zheng, "Sensitivity analysis of bursting liability for different coal-rock combinations based on their inhomogeneous characteristics," Geomatics, Natural Hazards and Risk, vol. 11, no. 1, pp. 149-159, 2020.

[24] S. S. Zhang, "Origin of oolitic clay rocks at the bottom of xiahuayuan formation in yu county, Hebei," Coal Geology \& Exploration, vol. 21, no. 3, pp. 9-11, 1994.

[25] J. F. Ju, Q. S. Li, J. L. Xu et al., "Self-healing effect of waterconducting fractures due to water-rock interactions in undermined rock strata and its mechanisms," Bulletin of Engineering Geology and the Environment, vol. 79, no. 6, pp. 287-297, 2020.

[26] B. Y. Jiang, L. G. Wang, S. T. Gu et al., "Failure mechanism and support design of deep composite soft rock roadway in Yangcheng coal mine," Journal of MiningぬSafety Engineering, vol. 33, no. 3, pp. 452-458, 2016.

[27] A. Afrouz, "Methods to reduce floor heave and sides closure along the arched gate roads," Mining Science and Technology, vol. 10, no. 3, pp. 253-263, 1990.

[28] E. Hoek and E. T. Brown, "Practical estimates of rock mass strength," International Journal of Rock Mechanics and Mining Sciences, vol. 34, no. 8, pp. 1165-1186, 1997.

[29] W. Yu and F. Liu, "Stability of close chambers surrounding rock in deep and comprehensive control technology," $A d-$ vances in Civil Engineering, vol. 2018, Article ID 6275941, 18 pages, 2018. 